\title{
The Supreme Court's Due Process Calculus for Administrative Adjudication in Mathews $v$. Eldridge: Three Factors in Search of a Theory of Value
}

\author{
Jerry L. Mashaw $\dagger$
}

In this article, Professor Mashaw examines and criticizes the Supreme Court's most recent attempt, in Mathews v. Eldridge, to formulate a due process calculus for administrative adjudication. According to Mashaw the failure of the Eldridge calculus is its emphasis on questions of technique rather than on questions of value. The Court, he proposes, should be systematically concerned with the various alternative value theories that the due process clause reflects. Finally, Mashaw indicates the contribution that such concerns might have made to the Eldridge analysis and to due process review in general.

During the 1970s the Supreme Court has undertaken an intensive review of administrative hearing procedures for conformity with constitutional requirements of due process of law. ${ }^{1}$ The landmark

$\dagger$ Professor of Law, Yale Law School. I wish to thank J. Kevin Buster for research assistance in the documentation of this article and Bruce Ackerman, Owen Fiss, Bill Nelson, Warren Schwartz, and Paul Verkuil for helpful comments on a prior draft. Full responsibility for the article's content is, of course, my own.

1 The Court's recent intensive involvement with administrative hearing processes began about 1969 and includes: Withrow v. Larkin, 421 U.S. 35 (1975) (bias in hearing before state board of medical examiners); Bowman Transp., Inc. v. Arkansas-Best Freight Sys., Inc., 419 U.S. 281 (1974) (lack of opportunity to offer contrary presentation of evidence in ICC hearing for issuance of "certificate of public convenience and necessity"); Wolff v. McDonnell, 418 U.S. 539 (1974) (procedural irregularities in prison disciplinary hearing); Calero-Toledo v. Pearson Yacht Leasing Co., 416 U.S. 663 (1974) (lack of notice and hearing prior to seizure of yacht by Puerto Rican transportation officials); Arnett v. Kennedy, 416 U.S. 134 (1974) (lack of hearing prior to employment termination of government employee); Weinberger $v$. Hymson, Westcott \& Dunning, Inc., 412 U.S. 609 (1973) (lack of hearing prior to the Food and Drug Administration's withdrawal of a "new drug application"); Gagnon v. Scarpelli, 411 U.S. 778 (1973) (lack of hearing prior to probation revocation); Gibson-4-Berryhill, 411 U.S. 564 (1973) (lack of impartial hearing officers in hearings before state optometry board); Perry v. Sindermann, 408 U.S. 593 (1972) (lack of hearing prior to employment termination of state employee); Board of Regents v. Roth, 408 U.S. 564 (1972) (lack of hearing prior to employment termination of state employee); Morrissey v. Brewer, 408 U.S. 471 (1972) (lack of hearing in parole revocation); Richardson v. Wright, 405 U.S. 208 (1972) (lack of opportunity to offer oral evidence and to cross-examine witnesses in hearing concerning termination of disability benefits); Connell v. Higgipbatham, 403 U.S. 207 (1971) (lack of hearing prior to employment termination of government employee); Bell v. Burson, 402 U.S. 535 (1971) (lack of hearing prior to suspension of driver's license); Richardson v. Perales, 402 U.S. 389 (1971) (admission of unsworn written medical reports as evidence at hearing for eligibility 
case of Goldberg $v . K^{2} l l y^{2}$ in 1970 confirmed the Court's unwillingness to limit its review by traditional notions of property interests and also suggested, in its specification of the constitutionally requisite elements of adjudicatory procedure, that the Court was prepared to assume a highly interventionist posture. What followed was a "due process revolution"-a flood of cases seeking to extend, or simply to apply, Goldberg's precepts. ${ }^{3}$

The basic task that this burgeoning due process case load has presented to the courts has been to give content to the requirements of due process while maintaining an appropriate judicial role in the design of administrative procedures. Although Goldberg may have indicated the Court's willingness to impose a detailed model of requisite adjudicatory procedure upon a particular administrative function, no recent Supreme Court has believed that a single model is readily and consistently applicable to all administrative functions. What is required, therefore, are general criteria for review that will lend consistency and principle to the Court's decisions while permitting different administrative functions to be reviewed on their own terms. At the same time, those general criteria should be sufficiently concrete to structure administrative behavior without resort to a judicial test of every procedure that lacks some element of the paradigm process advanced in Goldberg.

In the Court's latest attempt to formulate this due process calculus, Mathews $v$. Eldridge, ${ }^{4}$ Justice Powell's majority opinion articulates a set of criteria with a comprehensiveness that suggests a preliminary integration of the Court's recent efforts. ${ }^{5}$ In the major-

for disability benefits); Wisconsin v. Constantineau, 400 U.S. 433 (1971) (lack of hearing prior to public posting of names of people deemed unfit to consume alcoholic beverages); Rowan v. United States Post Office Dep't, 397 U.S. 728 (1970) (procedural irregularities in scheme for hearings concerning mail violations); Wheeler v. Montgomery, 397 U.S. 280 (1970) (lack of hearing prior to termination of old-age benefits); Goldberg v. Kelly, 397 U.S. 254 (1970) (lack of hearing prior to termination of public assistance benefits); Jenkins v. McKeithen, 395 U.S. 411 (1969) (cross-examination deficiencies in state commission hearings on possible violations of criminal laws relating to labor-management relations).

2397 U.S. 254 (1970).

${ }^{3}$ In addition to the many Supreme Court cases, see note 1 supra, hundreds of cases have been decided by the lower federal courts.

- 424 U.S. 319 (1976).

s Eldridge may also represent a turning point in the Court's resolution of procedural due process issues. Since Eldridge, plaintiffs in due process cases have been uniformly unsuccessful, and a marked tendency has emerged to avoid "balancing" analysis by finding the due process clause inapplicable. Montamye v. Haymes, 96 S. Ct. 2543 (1976) (lack of hearing prior to transfer of prison inmates); Meachum v. Fano, $96 \mathrm{~S}$. Ct. 2532 (1976) (lack of hearing prior to transfer of prison inmates); Bishop v. Wood, $96 \mathrm{~S}$. Ct. 2074 (1976) (lack of hearing prior to employment termination of city policemen); Paul v. Davis, 96 S. Ct. 1155 (1976) (lack of 
ity's words, from which there is no dissent, ${ }^{6}$ the Court must consider:

first, the private interest that will be affected by the official action; second, the risk of an erroneous deprivation of such interest through the procedures used, and the probable value, if any, of additional or substitute procedural safeguards; and finally, the Government's interest, including the function involved and the fiscal and administrative burdens that the additional or substitute procedural requisites would entail. ${ }^{7}$

Although this functional formulation impliedly invites an intrusive, particularistic review and specification of procedures, it is tempered by judicial restraint. "In assessing what process is due in this case, substantial weight must be given to the good-faith judgment of the individuals charged by Congress with the administration of the social welfare system that the procedure they have provided assure fair consideration of the entitlement claims of individuals."8

The thesis of this article is that the Eldridge approach is unsatisfactory both as employed in that case and as a general formulation of due process review of administrative procedures. The failing of Eldridge is its focus on questions of technique rather than on questions of value. That focus, it is argued, generates an inquiry that is incomplete because unresponsive to the full range of concerns embodied in the due process clause.

After examining Mathews $v$. Eldridge and criticizing the Court's application of the due process calculus which it advances, the article considers the contribution that systematic attention to alternative theories of due process values might have made to that analysis. Ultimately the plea is for a reorientation of judicial review of administrative procedure that would substitute a systematic concern with value for the intuitive functionalism of the Eldridge opinion. The argument is that this approach would be more consonant with accepted constitutional principles and with the Court's historic role as defender of constitutionally assured individual liberty.

hearing prior to distribution of list of names of people charged but not convicted of shoplifting).

- Although Justice Brennan questioned the application of these criteria to the facts, he refrained from questioning the criteria themselves. 424 U.S. 319, 349-50 (Brennan, J., dissenting); see Richardson v. Wright, 405 U.S. 208, 212 (1972) (Brennan, J., dissenting).

724 U.S. at 335.

s Id. at 349 . 


\section{Mathews v. EldRidge}

\section{A. The Disability Determination Process}

The plaintiff George Eldridge first filed an application for disability benefits with the defendant Social Security Administration (SSA) on March 10, 1967. His claim was processed through an adjudicatory system which is massive ${ }^{9}$ and complex-and increasingly unmanageable. ${ }^{10}$ The complexity of the system can be attributed to two factors: first, the problematic statutory definition of "disabil-

- The massiveness of the social security disability claims process is difficult to appreciate. For fiscal year 1975, the state agencies processed 1,230,200 initial determinations of disability and 221,800 reconsideration decisions. OfFCE of Management Administration, Social Security Administration, SSA Facts for Fiscal Year 1975 (OAAP Pub. No. 006 (2-76) 1976). For the same year there were 75,400 hearings held before administrative law judges. Id. In 1972, George Eldridge would have been one of $1,832,916$ disabled workers receiving social security disability benefits and one of about 38,000 such workers whose benefits were terminated during that year due to recovery. STApF of House Comm. on Ways and Means, 93d Cong., 2d Sess., Report on Disabiltty Insurance Program, 313, 347 (1975) [hereinafter cited as STAFF REPORT]. The system is so big that reliable data about it are difficult to obtain.

This same administrative system now processes Supplemental Security Income (SSI) claims. Supplemental Security Income for Aged, Blind, or Disabled, 42 U.S.C. $\$ \S 1381-1385$ (1974). (SSI federalized state old age, aid to the blind, and permanent and total disability programs.) Also, the system temporarily included "black lung" decisions under the 1972 Amendments to the Federal Coal Mine Health and Safety Act of 1969, 30 U.S.C. $\S \S 901-902$, 921-924, 931-934, 936-940, 951 (Supp. II, 1972).

11 A 1974 staff report to the House Committee on Ways and Means on the disability insurance program concluded that there was "a substantial question . . . whether the multitiered Social Security appeals procedure can withstand the current workload under social security and SSI, even if the present Black Lung situation is only a temporary aberration." StAFF REPORT, supra note 9, at 5. The fear was that the system was reaching a scale at which its complexity would render it unmanageable.

The apparently fragile condition of the Social Security Administration's hearings and appeals process strongly influenced the Government's petition for certiorari in Eldridge. In his petition the Solicitor General stated that

under the current administrative procedures governing determination of social security disability benefits, the Secretary presently terminates the benefits of approximately 87,600 disability beneficiaries (and their dependents) each year because their disabilities are found to have ceased. Of these terminations, fewer than 2,400 per year proceed to the post termination oral evidentiary hearings provided under current procedures. In the Secretary's judgment the court of appeals' holding that Goldberg v. Kelly, supra, requires the disability beneficiary to be afforded oral evidentiary hearings prior to termination, if allowed to stand will severely tax the capacity of the Social Security Administration to conduct an effective disability program, and will result in substantial losses to the social security trust fund.

Petitioner's Brief for Certiorari at 8, Mathews v. Eldridge, 424 U.S. 319 (1976). The trust fund, at current funding levels, is projected to be exhausted some time in 1979 and to have a deficit of nearly 9 billion dollars by 1982. Staff of Subcomm. on Social Security OF the House Comm. on Ways and Means, 94th Cong., 2d Sess., Disability Insurance-Legislative Issue Paper 2 (Comm. Print 1976) [hereinafter cited as Disability Insurance-Legislative Issue PAPER]. 
ity" and, second, the division of labor among a variety of administrative bodies-(1) the Bureau of Disability Insurance of the SSA, (2) state vocational and rehabilitation agencies, (3) administrative law judges, and (4) the Appeals Council of the SSA.

The statutory definition of disability requires that a worker demonstrate his "inability to engage in any substantial gainful activity by reason of any medically determinable physical or mental impairment which can be expected to result in death or which has lasted or can be expected to last for a continuous period of not less than 12 months ...."11 To satisfy that test the worker bears a continuing burden of showing by means of "medically acceptable clinical and laboratory diagnostic techniques"12 that his impairment is of such severity that he is unable not only to do his previous work but,

considering his age, education, and work experience, [to] engage in any other kind of substantial gainful work which exists in the national economy, regardless of whether such work exists in the immediate area in which he lives, or whether a specific job vacancy exists for him, or whether he would be hired if he applied for work. ${ }^{13}$

Except to the extent that the Social Security Administration has by regulation designated certain impairments as per se disabilities, ${ }^{14}$ the effect of a medical impairment on functional capacity for employment must be evaluated in light of various nonmedical factors. ${ }^{15}$

This elaborate determination is made through the following sequence of procedures. ${ }^{16}$ First an applicant applies at a district office of the SSA. There a claims official determines, on the basis of the claimant's prior earnings and contributions to the Social Security system, whether he is eligible for Social Security benefits. The case is then referred to a state agency, ${ }^{17}$ usually the state voca-

$" 42$ U.S.C. $\S 423(\mathrm{~d})(1)(\mathrm{A})(1970)$.

12 Id. $\$ 423(\mathrm{~d})(3)$.

${ }^{13}$ Id. $\S 423(\mathrm{~d})(2)(\mathrm{A})$.

1420 C.F.R. $\$ \S 204.1502(\mathrm{a}),(\mathrm{c})(1976)$.

${ }^{15}$ It has been argued that the Social Security Disability and Supplemental Security Income programs draw unwarranted distinctions among classes of disabled persons for purposes of making social welfare payments. See Liebman, The Definition of Disability in Social Security and Supplemental Security Income: Drawing the Bounds of Social Welfare Estates, 89 Harv. L. REv. 833 (1976). For a fuller description of the application of the disability test, see R. Dixon, Social Security Disability and Mass Justice 54-57 (1973).

16 The sequence of procedures which applies to both acceptance for benefits and termination is described in 20 C.F.R. $\$ \$ 404.901-.990$ (1976).

17 The involvement of state agencies seems peculiar since both benefits and administration are financed entirely by federal funds. However, Congress decided at the inception of 
tional and rehabilitation service, where an adjudication unit composed of a doctor and a lay "vocational specialist" develops medical and vocational evidence and makes an initial decision on the claim. If the state agency denies the claim and the SSA affirms that denial, the claimant is notified that he is entitled to a de novo reconsideration of his claim by the state agency. If a reconsideration is requested, the claim is reviewed by a different state agency unit.

Should the claim again be denied, the claimant is informed that he is entitled to a de novo hearing before an administrative law judge appointed pursuant to the federal Administrative Procedure Act. The administrative law judge is usually the first person to decide the case who has seen the claimant or heard any oral testimony or argument. If the claimant loses before the administrative law judge, he is entitled to request discretionary review by the Appeals Council of the Social Security Administration. ${ }^{18}$ If the Appeals Council dismisses the request or denies the claim on the merits, the claimant may then seek judicial review in a federal district court. At every stage prior to judicial review the record remains open and the claimant may adduce new evidence.

In order to ensure continued beneficiary eligibility, disability awards are reviewed periodically by an adjudication unit within the state agency. The procedures for the termination of benefits are essentially the same as those for the initial determination of eligibility, except that the state unit rather than the claimant initiates the process. ${ }^{19}$ Once the initial state unit recommendation has been reviewed and accepted by an examiner in the SSA Bureau of Disability Insurance, benefits are terminated effective two months after the month in which medical recovery is determined to have occurred. The beneficiary is notified of termination at the time he is notified of his right to a de novo reconsideration by a different state unit. If the beneficiary prevails at any stage after benefits have been terminated, he is entitled to retroactive payments..$^{20}$ Alternatively, the Secretary of HEW has a statutory right under certain conditions to recover payments which are later determined to be illegitimate. ${ }^{21}$

the disability program that it should be connected with vocational rehabilitation programs that are carried on primarily by the states. Presumably this procedure would have determinations made by persons who were experienced with both medical and vocational factors relevant to disability insurance and also would attach the claimant immediately to a system which would screen him for referral to vocational rehabilitation programs.

1" The Appeals Council sits in Arlington, Virginia.

" Mathews v. Eldridge, 424 U.S. 319, 335-39 (1976).

${ }^{20} 42$ U.S.C. $\S 404$ (1970); see 20 C.F.R. $\S \S 404.501$, .503-.504 (1976).

${ }^{21} 42$ U.S.C. $\S 404$ (1970). See generally 20 C.F.R. $\$ \S 404.501-.515$ (1976). 


\section{B. The Plaintiff: George Eldridge}

George Eldridge's experience exemplifies the operation of the foregoing sequence of procedures. ${ }^{22}$ After Eldridge first filed an application, a state agency review team in Virginia found him not to be disabled within the meaning of the Social Security Act. He requested a reconsideration, which affirmed the prior finding. He then filed a request for a hearing. The hearing examiner found Eldridge disabled and ordered disability insurance benefits paid to him. Notice of this award was sent to Eldridge in June 1968, accompanied by a statement that his claim would be reexamined in one year because by that time he might show a medical improvement justifying termination of the benefits. In 1969, accordingly, Eldridge's claim was reexamined, and in February 1970 the SSA determined that his disability had ceased and suspended his benefits. Eldridge requested a reconsideration of this determination. He also filed suit in federal district court, alleging that the SSA's failure to provide him with a hearing prior to the suspension of his benefits violated due process. The court ordered that payments be continued pending its decision. Meanwhile, the SSA affirmed the state agency's reconsideration decision sustaining the prior determination against Eldridge. Eldridge requested a hearing, and in March 1971 the hearing examiner found that his disability had not ceased. Shortly thereafter the district court suit was dismissed as moot.

In March 1972 the Virginia agency responsible for processing Social Security disability awards sent Eldridge a form letter and questionnaire concerning the current condition of his disability. ${ }^{23}$ Eldridge completed this questionnaire and returned it to the state agency indicating that in his opinion he had not improved. The state agency received medical reports from Eldridge's treating physician and from a psychiatric consultant. On May 16, 1972, Eldridge received a letter from the state agency stating, with reasons, that

${ }^{22}$ The following description draws on the Supreme Court's statement of facts in Mathews v. Eldridge, the district court opinion in that case, 361 F. Supp. 520 (W.D. Va. 1974), and the petition for certiorari and the briefs filed in the Supreme Court.

${ }^{23}$ The questionnaire was Form 454a, which asks the claimant: (1) whether he feels his medical condition is improved so that he can return to work; (2) whether his doctor has told him that he is able to return to work; (3) whether the doctor has placed significant restrictions on the kind of work he may do or the hours he may work; (4) to describe in functional terms the sort of limitations on lifting, bending, pushing, and so on that interfere with his work; (5) to list the name of any treating physician, hospital, or clinic; (6) whether he has worked in the past 12 months, if so how much, and if not why not; (7) whether he is receiving vocational rehabilitation services; and (8) whether he has any additional information that he believes might be important in reviewing his continuing entitlement to social security disability benefits. 
the medical evidence in his case indicated that he was able to work as of May 1972. The letter also stated that benefits would terminate after July 1972 if the agency's finding were affirmed by the SSA, but that a reasonable time would be granted him to obtain and submit additional information. ${ }^{24}$ Eldridge responded to this letter as follows:

In regards to your letter of May 16, 1972 asking for more evidence to prove my disability, I think you should already have enough evidence in my files to prove the disability already. Besides if I was able to work I would have worked because if I was able to work I could make more money than social security paid me. Another thing, if you will check my reports a little closer I think you will find that I have arthritis of the spine rather than a strained back as you stated in your letter. The people at the disability section in Richmond have never made a yes decision in my case, I have always had to have a hearing in order to get the decision made properly. Even at the last hearing that was held in my case I had to employ an attorney, and the examiner made his decision wholly in my favor and stated in his decision for me for my checks to continue without interruption. So go ahead and make your own decision in the case, I know I'm not able to work, if I ever get able to work I will, I will get by some way without the social security even though I've paid into it while I was able to work. ${ }^{25}$

In June the SSA affirmed the state agency's finding that Eldridge's disability had ceased and, accordingly, that benefits should terminate after July 1972. Eldridge was notified of this determination on July 7 , and was advised of his right to request a reconsideration within six months.

In August Eldridge again filed suit, alleging that the Secretary

24 The letter states in part:

You were initially found to be disabled due to chronic anxiety and back strain. In addition you have been found to have diabetes. Medical evidence shows no significant motional limitation of your back which would impose severe functional restrictions. Diabetes is under control and no complications have been noted, secondary to this. Although you remain somewhat anxious, there are no indications of continued emotional problems of sufficient severity to preclude all work for which you are qualified.

Therefore, disability benefits being paid on your social security number may be stopped unless additional evidence is submitted which shows that you are still unable to work because of your impairment.

Petition for Writ of Certiorari at 7 n.5, Mathews v. Eldridge, 424 U.S. 319 (1976).

${ }^{2 s}$ Appendix to Petition for Writ of Certiorari at 13-14, Mathews v. Eldridge, 424 U.S. 319 (1976). 
of $\mathrm{HEW}$, in whose name Social Security determinations are made, had no authority to stop his benefit payments without first affording him an opportunity to be heard. The gist of Eldridge's argument was that his experience clearly showed that he could not get a proper determination on his disability claim except at an oral hearing before a hearing examiner (now called an administrative law judge).

\section{The State of the Jurisprudence}

Mathews $v$. Eldridge represents the Supreme Court's first full dress opinion on the pretermination administrative procedures of a social welfare system since Goldberg $v$. Kelly. ${ }^{26}$ Indeed the Court had studiously avoided determining how Goldberg applied to other social welfare programs such as unemployment compensation benefits $^{27}$ and workman's compensation benefits; ${ }^{28}$ and in Richardson $v$. Wright ${ }^{29}$ in 1972, the Court had refused to decide a prior hearing claim involving termination of Social Security disability benefits on the ground that HEW had promulgated new regulations pending review-the regulations at issue in Eldridge.

The Court's resolution in the Eldridge case-against George Eldridge - was difficult to predict on the basis of earlier due process decisions. The Court had often emphasized the flexibility of its approach to due process and the necessity of evaluating each claim virtually on its own facts..$^{30}$ Furthermore, as the multiple opinions in Arnett $v$. Kenned $y^{31}$ demonstrate, the Court had seemingly developed two lines of due process jurisprudence. One line suggested a presumption in favor of prior evidentiary hearings: the deprivation of any substantial interest prior to an opportunity for hearing would have to be justified by some reasonably compelling governmental necessity. ${ }^{32}$ The other line seemed to reverse that presumption: sum-

${ }^{26} 397$ U.S. 254 (1970).

${ }^{27}$ See Fusari v. Steinberg, 419 U.S. 379 (1975); Indiana Employment Security Div. v. Burney, 409 U.S. 540 (1973); Tocres v. New York Dep't of Labor, 405 U.S. 949 (1972); California Dep't of Human Resources Dev. v. Java, 402 U.S. 121 (1971). See also Christian v. New York Dep't of Labor, 414 U.S. 614 (1974). 1972).

${ }^{28}$ Dillard v. Industrial Comm'n, 414 U.S. 1110 (1974), aff'g 347 F. Supp. 71 (E.D. Va.

405 U.S. 208 (1972).

${ }^{30}$ E.g., Wolff v. McDonnell, 418 U.S. 539 (1974); Morrissey v. Brewer, 408 U.S. 471 (1972); Richardson v. Perales, 402 U.S. 389 (1971); Hannah v. Larche, 363 U.S. 420 (1960).

31416 U.S. 134 (1974).

32 Fuentes v. Shevin, 407 U.S. 67 (1972); Bell v. Burson, 402 U.S. 535 (1971); Goldberg v. Kelly, 397 U.S. 254 (1970); Sniadach v. Friendly Fin. Corp., 395 U.S. 337 (1969). See also Regal Drug Corp. v. Wardell, 260 U.S. 386 (1922); Lipke v. Lederer, 259 U.S. 557 (1922); Hagar v. Reclamation District, 111 U.S. 701 (1884); Springer v. United States, 102 U.S. 586 (1880). 
mary process that preliminarily disposed of property or other interests was acceptable, provided there was later opportunity for a hearing that might lead to a reinstatement of the interest. ${ }^{33}$

A reconciliation of these two lines of due process jurisprudence was nevertheless quite feasible. In the cases requiring prior hearing, with the exception of Goldberg, there had been no notice or opportunity to contest of any kind before adverse administrative action was taken; and the Court in those cases was not required to reach the issue of what form of prior procedure would satisfy due process. On the other hand, almost all of the cases permitting summary action without hearing involved a governmental necessity or emergency. Standing between these lines of cases Eldridge, like Goldberg, posed the question whether a full evidentiary hearing was required prior to the divestiture of a substantial interest when some opportunity to contest had been provided and no overriding governmental interest in summary process was apparent. In upholding the Social Security Administration's termination procedures, therefore, the Supreme Court may have determined that the Goldberg situation was unique.

\section{The Due Process Calculus as Applied in Mathews v. ELDRidge}

\section{A. The Private Interest}

Because the SSA makes retroactive payments when it reinstates a recipient after a hearing, the Eldridge Court articulated the plaintiff's substantive interest as an interest merely "in the uninterrupted receipt of his source of income pending final administrative decision of his claim." The Court conceded that this was the same interest as that of the welfare recipient in Goldberg $v$. Kelly, but it then distinguished the Eldridge facts on the ground that Goldberg had involved an income maintenance scheme of last resort for those in financial need, while the Social Security disability system in Eldridge made payments to the disabled irrespective of financial necessity. ${ }^{34}$

${ }^{33}$ Ewing v. Mytinger \& Casselberry, Inc., 339 U.S. 594 (1950); Lichter v. United States, 334 U.S. 742 (1948); Fahey v. Mallonee, 332 U.S. 245 (1947); Bourjois, Inc. v. Chapman, 301 U.S. 183 (1937); Nickey v. Mississippi, 292 U.S. 393 (1934); United States v. Mlinois Cent. R.R., 291 U.S. 457 (1934); Phillips v. Commissioner, 283 U.S. 589 (1931); Coffin Bros. \& Co. v. Bennett, 277 U.S. 29 (1928); Stoehr v. Wallace, 255 U.S. 239 (1921); Wells Fargo v. Nevada, 248 U.S. 165 (1918); Public Clearing House v. Coyne, 194 U.S. 497 (1904); Lawton v. Steele, 152 U.S. 133 (1894); Walston v. Nevin, 128 U.S. 578 (1888); Kentucky R.R. Tax Cases, 115 U.S. 321 (1885).

s Mathews v. Eldridge, 424 U.S. 319, 340-41 (1976). 
Justice Powell conceded that "[although] the potential deprivation here is generally likely to be less than in Goldberg . . . the degree of difference can be overstated." ${ }^{35} \mathrm{He}$ went on to note that the possible length of wrongful deprivation is one consideration in judging the impact of official action on private interests and that the Social Security hearing process, which now disposes of claims more than a year after a hearing request, is "torpid." 36 The Court also noted the typically modest resources of a physically disabled worker ${ }^{37}$ and the significant possibility that ineligibility for federal disability payments would also render a recipient ineligible for the most logical welfare program, Supplemental Security Income (SSI), which uses the same definition of disability. Notwithstanding these observations, however, the Court concluded that since a disability recipient might have access to private resources and other forms of government assistance beyond those normally available to welfare recipients like the one in Goldberg, there was "less reason here than in Goldberg to depart from the ordinary principle, established by our decisions, that something less than an evidentiary hearing is sufficient prior to adverse administrative action." 38

Despite its fairly careful analysis, the Court's approach to weighing the private interest is incomplete and problematic. If the objective, as the Court's due process calculus suggests, is to compare the monetary value of the private interests in avoiding wrongful terminations prior to hearing with the monetary value of the governmental interest in summary termination, the Court should have computed the total value of terminated SSA disability claims. Given the current success rate on appeal, that figure might then be discounted by about $50 \%{ }^{39}$ This discounted value would also have

ss Id. at 341 .

${ }^{36}$ Id. at 342 .

${ }^{37}$ Id. at 342 \& n.26. According to the 1966 Social Security Survey of the Disabled, the physically disabled worker's family unit has a median income of $\$ 2,836$ and median liquid assets of $\$ 940$. More recent statistics on the income and assets of disabled workers are not available. Note, however, that the 1966 survey included persons who considered themselves disabled but who were not receiving and probably could not qualify for Social Security disability benefits. According to that same survey, more than three-fifths of the severely disabled had incomes below $\$ 3,000$ and over three-fourths had incomes less than $\$ 5,000$ per year. About half had incomes below the poverty level as of 1966. See I. Swisher, Sources and Size of Income of Disabled (Social Security Survey of the Disabled: 1966, Report No. 16, June, 1971).

3x 424 U.S. at 343.

39 According to the Operational Analysis of the Bureau of Hearings and Appeals of the Social Security Administration for the fiscal year 1972, approximately $39 \%$ of all decisions by administrative law judges were favorable to the claimant. By fiscal year 1975 that figure had risen to $42 \%$. The Supreme Court, using a different statistical base, put the reversal rate at nearly $60 \% .424$ U.S. at 346. 
made an interesting comparison with the total value of terminated welfare claims, discounted by perhaps $75 \%$ to reflect the lesser success rate of appellants from adverse welfare determinations. ${ }^{40}$ For purposes of comparing the social loss from erroneous termination of welfare and disability benefits, the Court might also have wanted to know the median and mean values of disability benefit claims as compared with welfare benefit claims. Yet, neither the briefs nor the Court's opinion discuss these questions.

Rather the Court's approach is subjective and impressionistic. Its stated concern is the potential desperation resulting from adverse administrative action, a concern that is obviously germane but that raises some rather severe analytic difficulties. First, the Court assumes that interpersonal comparisons of utility, or disutility, are possible-a position which, though intuitively appealing, has no scientific support. ${ }^{41}$ Second and more importantly, the Court assumes that these interpersonal comparisons hold across the total populations of welfare and disability recipients when it assumes that disability recipients are less dependent on income support than welfare recipients. This assumption is buttressed only by the notion that welfare is for the needy and disability insurance is for prior taxpayers. The simple rejoinder is that in both cases a recipient's most important residual asset is his or her human capital; since a terminated welfare recipient has never been adjudged unable to perform any substantial gainful activity in any region of the country, he or she might a priori be considered better off than a terminated disability recipient. In fact, any number of circumstances might make a terminated welfare recipient's plight less desperate than that of his disabled SSA counterpart, ${ }^{42}$ or vice versa. But any wholesale assumption in favor of either group so grossly overgeneralizes the positions of individual recipients that it masks grave potential injustice.

\section{B. The Value of Additional Procedural Safeguards}

The Court's analysis of the reliability of existing pretermina-

so The latest figures show that from January to June, $1975,27 \%$ of fair hearing claimants were successful. Dep't of Housing, Education, and Welfare, Fair Hearings in Public Assistance 1 (DHEW Pub. No. (SRS) 76-03257, 1976).

"See, e.g., K. Arrow, Social Choice and Individual Values 3-6 (1951).

12 The terminated AFDC recipient may have access to home or general relief depending upon his residence, whereas the disability claimant in a different state or locality may not. The disability claimant may be totally dependent for his livelihood on the disability payments, whereas the welfare recipient who is terminated may have been receiving a small AFDC payment to supplement inadequate family earnings. 
tion procedures and the probable value of additional procedural safeguards is as unsatisfactory as its analysis of the private interest at stake. The Court reached substantially three conclusions: (1) that it was dealing with an essentially medical determination, (2) that oral presentation would add little reliability to the existing written procedures, and (3) that the statistics on reversal rates at hearings, although noteworthy, did not by themselves impugn the reliability of the procedure.

First, the Court characterized the "nature of the relevant inquiry" as essentially a medical assessment of a worker's physical or mental condition. This assessment, as the Court viewed it, was "a more sharply focused and easily documented decision than the typical determination of welfare entitlement." 43 Pursuing this comparison, the Court suggested that whereas welfare determinations involved issues of witness credibility and veracity, disability determinations turned on "routine, standard and unbiased medical reports by physical specialists." 44 Relying on its language in Richardson $v$. Perales, the Court stated that "[ $t]$ he spectre of questionable credibility and veracity is not present." 45

The Court then dealt with, and dismissed, the Goldberg decision's requirement of an oral presentation to the decision maker. While noting that the Goldberg decision had relied on the limited educational attainment and deficient writing ability of welfare recipients, the Court did not attempt to distinguish disability recipients from welfare recipients on this basis. ${ }^{46}$ Rather, the Court emphasized two other aspects of the disability process that suggested the sensibleness and reliability of a written presentation of evidence. The first was that a disability claimant was likely to have much more information than a welfare claimant concerning the precise issues that were relevant to an entitlement decision. Second, evidence in the disability case, according to the Court, derived pri-

13424 U.S. at 343.

"Id. at 344, quoting Richardson v. Perales, 402 U.S. 389, 404 (1971).

is 424 U.S. at 344, quoting Richardson v. Perales, 402 U.S. 389, 407 (1971).

16 It seems highly unlikely that the two classes of beneficiaries are substantially different in terms of those socio-economic factors that relate to their ability to participate in hearings, either orally or in writing. Again quoting from the 1966 Social Security Survey of the Disabled, "in terms of education and occupation at the onset of disability . . . [c]lose to twothirds had eight years of schooling or less; only about one-fifth completed high school, about half of the men . . . had been employed at predominantly semi-skilled and unskilled occupations and only about one-sixth had had white collar jobs." L. Haber, The Disabled Beneficiary-A Comparison of Factors Related to Benefit Entitlement (Social Security Survey of the Disabled: 1966, Report No. 7, June, 1969). 
marily from sources other than the claimant: physicians' written reports and records, supplemented by $\mathrm{X}$ rays and documents reflecting other clinical or laboratory tests. The Court was also impressed that the agency informed the recipient of its tentative assessment and then provided an opportunity to submit additional written evidence, thus enabling the recipient to challenge directly the agency's information as well as its tentative conclusions.

The Court was nevertheless troubled, though not ultimately persuaded, by the apparently high reversal rate $(58.6 \%)$ for appealed reconsideration decisions, that is, decisions that go to hearing before an administrative law judge. ${ }^{47}$ What was unclear, however, was whether the reversal rate should be computed from the standpoint of appealed reconsideration decisions or from the standpoint of the overall adjudicatory process, including appealed and unappealed decisions. Under the latter approach, the reversal rate was only $3.3 \% .^{48}$ Furthermore, the Court was uncertain about the meaning of the reversal rate in terms of the reliability of initial and reconsideration decisions, since the "open file" concept in disability determinations means that the decision at the hearing may be based on additional or new medical evidence that was unavailable at the time of the initial or reconsideration decision. ${ }^{49}$

Again the Court's analysis is problematic. First, its characterization of the type of decision involved is incomplete. Certainly the definition of "disability" in the Social Security Act requires that disability be the result of a determinable physical or mental impairment. But the question whether the complaining party is disabled often requires the decision maker to translate this medical impairment into functional limitations and to evaluate the effect of those functional limitations on the claimant's capacity to engage in substantial gainful activity, given his age, education, and work experience. Thus a procedure that begins with routine medical reports concerning clinical diagnosis and treatment becomes a highly judgmental process requiring at least the following additional determi-

17424 U.S. at 346.

" Perhaps the most important unanswered question concerning the appeals process in Social Security disability claims is whether the unappealed decisions differ significantly, on their merits, from appealed decisions. Many persons who are knowledgeable about the system through long experience believe that there is little difference between appealed and unappealed denials, save the assertiveness of the claimant. See, e.g., Yourman, Report on a Study of Social Security Beneficiary Hearings, Appeals, and Judicial Review, in Subcomm. on Social Security of the House Comm. on Ways and Means, 94th Cong., Ist Sess., Recent Studies Relevant to the Disability Hearings and Appeals Crisis 134 (1975).

" There is no reliable statistical information on the percentage of hearing cases that involve additional or new evidence. 
nations: (1) the degree to which disease or trauma has produced impairments, that is, abnormalities in the claimant's physical or mental structure; (2) the degree to which these impairments result in activity losses or restrictions, usually characterized as functional limitations; (3) the degree to which the claimant's impairments and functional limitations affect the required capacities for the performance of normal roles and activities, including an analysis of attendant therapeutic limitations, environmental restrictions, energy reserve losses, and psychological overlays; (4) the interaction of the claimant's age, education, and prior work experience with his functional limitations and his response to them, and the effect of this combination of factors on his capacity for work available in the national economy. ${ }^{50}$ The importance of live testimony in this decision process, particularly by the claimant, has been recognized by several circuit courts of appeal..$^{51}$

Furthermore, according to recent studies by the staff of the House Ways and Means Committee, ${ }^{52}$ only $29 \%$ of the awards to those persons who are awarded disability benefits are made on the basis of medical condition alone. The basis of the remaining decisions to award benefits is either that impairments are functionally equivalent to those medical conditions which are per se disabling (45\%) or that, although the impairment does not meet or functionally equal the medical listings in the regulations, vocational factors specific to the individual justify a determination of total disability (26\%).

George Eldridge's fundamental complaint, therefore, might well be that the state agency was making a "medical" decision when it should have made a "disability" decision. His concern is not necessarily with the "veracity" of the medical evidence but rather with the capacity of a disability adjudicator to make a decision about his disability without seeing him and his response to his medical problem. If that is Eldridge's claim, the Court's characterization of the decision as medical and its discussion of the importance of an oral presentation are rather unresponsive: Eldridge might sensibly claim that his disability could not be reliably determined by an adjudicator who had not seen and heard him even if, as a general matter, disability claimants were substantially different socioeco-

so See Haber, Identifying the Disabled: Concepts and Methods in the Measurement of Disability, 1967 Soc. SEcurrTy Bull. 17, 18-20.

${ }^{51}$ See Underwood v. Ribicoff, 298 F.2d 850, 851-52 (4th Cir. 1962).

52 Disability Insurance-Legislative Issue Paper, supra note 10, at 17. 
nomically from welfare recipients-which they are not ${ }^{53}$ - and even if the notice of the SSA's preliminary determinations gave a claimant a good idea of the precise issues upon which his case had turned-which they do not. ${ }^{54}$ Three studies by the Social Security Administration have all confirmed that a face-to-face encounter with the claimant has a substantial positive correlation with acceptance of the claim. ${ }^{55}$

The Court might respond, of course, that the purpose of administrative adjudication is not to give an income maintenance claimant the best chance of winning. The question is whether the procedure he has been accorded gives a reasonable chance of producing reliable decisions. The Court's approach to the question of reliability, however, is no more thorough than its analysis of the nature of the decision.

Perhaps the best evidence of reliability is whether the decisions that are made, through whatever procedures, are in fact accurate. But what does "accuracy" mean in the disability system? The fact that over $50 \%$ of appealed cases are reversed was not sufficient in the Court's view to indicate that the SSA's underlying process produces inaccurate decisions. This may be perfectly sensible: not only might a finding of disability on appeal simply reflect the worsening of a previously nondisabling impairment, but more fundamentally there is no external standard for determining whether the initial or the appeal decision was accurate. There is also reason to believe that decisions made at the state agency level and at the appeal level

${ }^{3}$ See R. Dixon, supra note 15, at 21-23.

st The notice that George Eldridge received is set out above in relevant part. See note 24 supra. There is no reason to believe that it is more or less informative than the general run of Social Security disability termination notices. Because that notice failed to inform Eldridge either of the clinical findings contained in medical reports submitted to the state agency or of what jobs the state agency believed Eldridge was fit to perform, it adds little specificity to the statement of the disability standard in the Social Security Act.

is A Social Security Administration study of the effect of face-to-face interviews at the reconsideration stage conducted from December, 1970 to May, 1971 revealed that the faceto-face interview resulted in an award to the claimant in an additional $20 \%$ of cases beyond those normally reversed at the reconsideration stage. STAFF REPORT, supra note 9, at 240-41. A restudy conducted from January, 1975 to May, 1976 confirms these findings: $29 \%$ of initial determinations were reversed at the reconsideration stage without a face-to-face interview; $46 \%$ of the initial denials were reversed with a face-to-face interview. Statistical study in author's files (1976). These findings comport with a 1969 study of the hearing process that compared the reversal rate for cases that went before administrative law judges without a personal appearance of the claimant and those in which the claimant appeared. In 1968, the last year for which data were available, appearance of the claimant at the hearing, with or without representation, increased his chances of a favorable decision by nearly $20 \%$. See Rock \& Berwanger, An Evaluation of the SSA Appeals Process 3 (Progress Report No. 6, March, 1969). 
may differ because the two sets of adjudications do not act wholly within the same legal framework. The Disability Insurance State Manual, which attempts to objectify the disability standard in order to render state disability decisions more consistent, is not used by the administrative law judges who hold hearings in disability insurance cases. Instead, these judges apply the statutory standard, embellished only by the regulatory medical listings-listings that are almost always irrelevant to cases that reach the hearing stage. The discrepancy, then, between administrative law judges and state agency personnel may be one that flows from the difference between a hierarchical, bureaucratic decision-making system with relatively specific standards and a hearing process designed to provide individualized justice pursuant to general statutory criteria.

Given the absence of an objective external standard for accuracy and the possible noncomparability of decisions by state agencies and those by administrative law judges, the reliability of state agency decision making should be measured by some means other than the percentage of decisions that successfully withstand appeal. The nearest approximation to an index of accuracy is consistency in adjudication: if like cases are being treated alike by state agencies, then claimants are at least receiving formal justice through the existing procedures. In a closed hierarchical structure with no external referents consistency and accuracy tend to merge.

The General Accounting Office (GAO) recently completed a consistency survey of state agency disability determinations, ${ }^{56}$ and

${ }^{56}$ 'The GAO's survey has not yet been printed. Its results are summarized in the following table.

TABLE 2.-Variation in decisions among the States in 221 Cases

\begin{tabular}{|c|c|c|c|c|c|c|}
\hline \multirow[b]{2}{*}{ State } & \multicolumn{2}{|c|}{ Approved claim } & \multicolumn{2}{|c|}{ Denied claim } & \multicolumn{2}{|c|}{$\begin{array}{c}\text { Additional documenta- } \\
\text { tation needed to ren- } \\
\text { der decision } \\
\end{array}$} \\
\hline & Number & Percent & Number & Percent & Number & $\begin{array}{c}\text { Percent } \\
\text { Pant }\end{array}$ \\
\hline State of ongin $\ldots \ldots \ldots$ & 113 & 51 & 108 & 49 & (1) & (') \\
\hline A $\ldots \ldots \ldots \ldots \ldots \ldots$ & 81 & 37 & 71 & 32 & 69 & 31 \\
\hline B $\ldots \ldots \ldots \ldots \ldots \ldots$ & 104 & 47 & 55 & 25 & 62 & 28 \\
\hline $\mathrm{C} \quad \ldots \ldots \ldots \ldots \ldots, \ldots$ & 74 & 34 & 54 & 24 & 93 & 42 \\
\hline $\mathrm{D} \quad \ldots \ldots \ldots \ldots \ldots, \ldots$ & 86 & 39 & 54 & 24 & 81 & 37 \\
\hline $\mathrm{E} \quad \ldots \ldots \ldots \ldots \ldots \ldots \ldots$ & 91 & 41 & 90 & 41 & 40 & 18 \\
\hline $\mathrm{F} \ldots \ldots \ldots \ldots \ldots \ldots \ldots$ & 68 & 31 & 43 & 20 & 110 & 50 \\
\hline G $\ldots \ldots \ldots \ldots \ldots \ldots$ & 91 & 41 & 53 & 24 & 77 & 35 \\
\hline$H \ldots \ldots \ldots \ldots \ldots$ & 99 & 45 & 58 & 26 & 64 & 29 \\
\hline$\ldots \ldots \ldots, \ldots, \ldots$, & 91 & 41 & 75 & 34 & 55 & 25 \\
\hline $\mathrm{J}, \ldots \ldots \ldots, \ldots, \cdots$ & 91 & 41 & 54 & 25 & 76 & 34 \\
\hline Federal (BDI & & & & & & \\
\hline Baltimore) $\ldots$. & 55 & 25 & 59 & 27 & 107 & 48 \\
\hline
\end{tabular}


the results are not encouraging. By random sample the GAO selected 221 SSA and SSI disability claims that had been adjudicated by a state agency; it then transmitted copies of the claims files to ten other state agencies and to federal adjudicators in the Bureau of Disability Insurance in Baltimore. There was significant lack of agreement among state agencies and between state agencies and the federal adjudicators. More importantly, in nearly $50 \%$ of the cases, state agencies and federal adjudicators believed that the furnished documentation was insufficient to reach a decision. ${ }^{57}$

If "accuracy" is meaningless and consistency unachievableor at least unachieved-what does that imply concerning George Eldridge's claim for an oral evidentiary hearing? It seems doubtful that such a hearing would make the process more accurate or consistent, for there is still no external standard for accuracy, and de novo, individualized, oral hearings are hardly an apt control over inconsistent decisions. But Eldridge's claim may make sense precisely because accuracy and consistency are so elusive in this system. SSA disability adjudications should perhaps be viewed as really concerned with difficult value judgments-individualized exemptions from the moral, social, and economic constraints of the work ethic, determined by a complex of medical, vocational, and environmental factors as they impinge on particular individuals. Such adjudications by their very nature elude objective verification and cannot be effectively controlled for consistency. Accordingly, they can be legitimized only by invoking either authority or consent. In a democracy consent is undoubtedly the preferable justification. Its procedural approximation would seem to be the fullest possible participation in the decisional process.

\section{The Public Interest}

The cost to the public of providing pretermination hearings is two-fold: (1) the direct costs of additional hearings, and (2) the costs of disability benefits paid to current, ineligible recipients pending a hearing decision. In view of the widely varying estimates in the Mathews $v$. Eldridge briefs, ${ }^{58}$ the Court was unwilling to

\footnotetext{
Disability Insurance-Legislative Issue Paper, supra note 10.

57 In only $32 \%$ of the cases were the states in complete agreement on whether the claims should have been granted or denied. Moreover, in only 156 of the 221 cases was it possible for a majority of the state agencies to reach agreement on whether to approve or deny the claim. And, when GAO could find a majority of states in accord on the result in a case, it found that in $95^{\circ} ;$ of those cases the states disagreed on the rationale for the decision. The Federal adjudicators agreed with a majority of the states in less than half the cases.

${ }^{3 k} 424$ U.S. at 347.
} 
hazard a guess concerning the magnitude of these costs. It was content to say that "experience with the constitutionalizing of government procedures suggests that the ultimate costs in terms of money and administrative burden would not be insubstantial."s There was no indication of what "experience" the court was relying on. Thereafter the Court lapsed into speculation about the possibility that increased costs would be paid, somehow, by the deserving recipients of the program and indulged in generalities concerning the folly of transplanting judicial-type procedures willy-nilly to administrative processes. In the end the Court fell back on judicial self-restraint. ${ }^{60}$

The Court was perhaps sensible to sidestep the question of the social costs of pretermination hearings. Apparently no reliable information exists on the motivation of claimants for pursuing appeals in the Social Security system, or on the impact of Goldberg $v$. Kelly on the welfare system. Comparative statistics on requests for pretermination oral hearings under the SSI program are also unavilable. Thus no one can project the impact of a right to pretermination hearings on the rate of appeal. Moreover, the final costs would depend on how the Social Security Administration restructured the hearing process to incorporate a requirement for pretermination hearings. For example, losses from paying aid pending benefits might be minimized by speeding up the entire process; and the reconsideration level in termination cases might be discarded in favor of an oral conference at the state agency level. Whether such restructuring would offset the costs engendered by a new incentive to appeal is wholly problematic.

\section{A Value-Sensitive Approach to the Eldridge ANalysis of Due Process}

The Supreme Court's analysis in Eldridge is not informed by systematic attention to any theory of the values underlying due process review. The approach is implicitly utilitarian but incomplete, and the Court overlooks alternative theories that might have yielded fruitful inquiry. This section attempts, first, to articulate the limits of the Court's utilitarian approach, both in Eldridge and as a general schema for evaluating administrative procedures, and second, to indicate the strengths and weaknesses of three alternative theories-individual dignity, equality, and tradition. These theo-

\footnotetext{
58 Id.

Soe text at note 8 supra.
} 
ries, at the level of abstraction here presented, require little critical justification: they are widely held, respond to strong currents in the philosophic literature concerning law, politics, and ethics, and are supported either implicitly or explicitly by the Supreme Court's due process jurisprudence. ${ }^{61}$

\section{A. Utilitarianism}

Utility theory suggests that the purpose of decisional procedures-like that of social action generally-is to maximize social welfare. Indeed, the three-factor analysis enunciated in Eldridge appears to be a type of utilitarian, social welfare function. That function first takes into account the social value at stake in a legitimate private claim; it discounts that value by the probability that it will be preserved through the available administrative proce-

"In early due process cases the Supreme Court concentrated on tradition. The oft-cited statement in Davidson v. New Orleans, 96 U.S. 97, 104 (1877), that the Court's approach to due process problems should be "by the gradual process of judicial inclusion and exclusion," epitomizes the conservative, precedent-oriented, historical approach. As governmental functions increased, however, the Court was faced with due process problems that had no compelling historical analogies. If the Court was not to be a continual stumbling block to "progress," a more flexible approach was needed. Indeed, the history of due process in the Supreme Court might be characterized as a continuous search for a theory of due process review that combines the legitimacy of the evolutionary theory with a flexibility that permits adaptation to contemporary circumstances. Dignitary or natural right, utilitarian, and egalitarian theories have all been incorporated to this end.

Dignitary ideas, although used occasionally in a supportive role both before 1900 and in some contemporary cases, were employed most frequently as the primary mode of analysis from about 1933 through the early 1950 s. The proliferation of new government functions associated with the New Deal legislation and, later, with emergency war measures, stimulated a judicial reaction that was captured in the Court's emphasis on individual rights and dignitary values. The reactive natural rights style, predicated upon the Justices' perception of the "fair" solution in each case, had an ad hoc quality that soon became disturbing. The apparent inconsistency of the Supreme Court's due process jurisprudence led Sanford Kadish in a seminal article to describe the Supreme Court's decisions as in "chaotic array." Kadish, Methodology and Criteria in Due Process Adjudication-A Survey and Criticism, 66 Yale L.J. 319 (1957).

In the late 1950 s and early 1960 s various utilitarian formulations began to supply a structure for analysis. In Cafeteria \& Restaurant Workers Local 473 v. McElroy, 367 U.S. 886, 895 (1961), for example, the Court, per Mr. Justice Stewart, stated that two factors must be considered in due process cases: "the precise nature of the government function involved ... [and] of the private interest that has been affected by government action." The statement of the utilitarian approach culminates in the Eldridge opinion's three-factor calculus.

Equality as a due process value has received considerable attention in criminal (or quasicriminal) cases, but little outside that area. Perhaps the best example of the explicit use of equality concerns with respect to an administrative function is found in Ashbacker Radio Corp. v. FCC, 326 U.S. 327, 330 (1945). There the Court, per Mr. Justice Douglas, stated that the right to a hearing "becomes an empty thing" unless all parties affected by the process have an equal opportunity to be heard. 
dures, and it then subtracts from that discounted value the social cost of introducing additional procedures. When combined with the institutional posture of judicial self-restraint, utility theory can be said to yield the following plausible decision-rule: "Void procedures for lack of due process only when alternative procedures would so substantially increase social welfare that their rejection seems irrational."

The utilitarian calculus is not, however, without difficulties. The Eldridge Court conceives of the values of procedure too narrowly: it views the sole purpose of procedural protections as enhancing accuracy, and thus limits its calculus to the benefits or costs that flow from correct or incorrect decisions. ${ }^{62}$ No attention is paid to "process values" that might inhere in oral proceedings or to the demoralization costs that may result from the grant-withdrawalgrant-withdrawal sequence to which claimants like Eldridge are subjected. Perhaps more important, as the Court seeks to make sense of a calculus in which accuracy is the sole goal of procedure, it tends erroneously to characterize disability hearings as concerned almost exclusively with medical impairment and thus concludes that such hearings involve only medical evidence, whose reliability would be little enhanced by oral procedure. As applied by the Eldridge Court the utilitarian calculus tends, as cost-benefit analyses typically do, to "dwarf soft variables" and to ignore complexities and ambiguities.

The problem with a utilitarian calculus is not merely that the Court may define the relevant costs and benefits too narrowly. However broadly conceived, the calculus asks unanswerable questions. For example, what is the social value, and the social cost, of continuing disability payments until after an oral hearing for persons initially determined to be ineligible? Answers to those questions require a technique for measuring the social value and social cost of government income transfers, but no such technique exists. Even if such formidable tasks of social accounting could be accomplished, the effectiveness of oral hearings in forestalling the losses that result from erroneous terminations would remain uncertain. In the face of these pervasive indeterminacies the Eldridge Court was forced to retreat to a presumption of constitutionality. ${ }^{63}$

Finally, it is not clear that the utilitarian balancing analysis asks the constitutionally relevant questions. The due process clause

22 For a relatively complete development of this approach, see Posner, An Economic Approach to Legal Procedure and Judicial Administration, 2 J. LEgal STud. 399 (1973).

s See text at note 8 supra. 
is one of those Bill of Rights protections meant to insure individual liberty in the face of contrary collective action. Therefore, a collective legislative or administrative decision about procedure, one arguably reflecting the intensity of the contending social values and representing an optimum position from the contemporary social perspective, cannot answer the constitutional question of whether due process has been accorded. A balancing analysis that would have the Court merely redetermine the question of social utility is similarly inadequate. There is no reason to believe that the Court has superior competence or legitimacy as a utilitarian balancer except as it performs its peculiar institutional role of insuring that libertarian values are considered in the calculus of decision.

Several alternative perspectives on the values served by due process pervade the Court's jurisprudence, ${ }^{64}$ and may provide a principled basis for due process analysis. These perspectives can usually be incorporated into a broadly defined utilitarian formula and are therefore not necessarily antiutilitarian. But they are best treated separately because they tend to generate inquiries that are different from a strictly utilitarian approach.

\section{B. Individual Dignity}

The increasingly secular, scientific, and collectivist character of the modern American state reinforces our propensity to define fairness in the formal, and apparently neutral language of social utility. Assertions of "natural" or "inalienable" rights seem, by contrast, somewhat embarrassing. Their ancestry, and therefore their moral force, are increasingly uncertain. ${ }^{65}$ Moreover, their role in the history of the due process clause makes us apprehensive about their eventual reach. It takes no peculiar acuity to see that the tension in procedural due process cases is the same as that in the now discredited substantive due process jurisprudence-a tension between the efficacy of the state and the individual's right to freedom from coercion or socially imposed disadvantage.

Yet the popular moral presupposition of individual dignity, and its political counterpart, self-determination, persist. State coercion must be legitimized, not only by acceptable substantive policies, but also by political processes that respond to a democratic morality's demand for participation in decisions affecting individual and

"See note 61 supra.

is See generally Woodward, The Limits of Legal Realism: An Historical Perspective, 54 VA. L. REv. 689 (1968). 
group interests. ${ }^{66}$ At the level of individual administrative decisions this demand appears in both the layman's and the lawyer's language as the right to a "hearing" or "to be heard," normally meaning orally and in person. ${ }^{67}$ To accord an individual less when his property or status is at stake requires justification, not only because he might contribute to accurate determinations, but also because a lack of personal participation causes alienation and a loss of that dignity and self-respect that society properly deems independently valuable. ${ }^{68}$

The obvious difficulty with a dignitary theory of procedural due process lies in defining operational limits on the procedural claims it fosters. In its purest form the theory would suggest that decisions affecting individual interests should be made only through procedures acceptable to the person affected. This purely subjective standard of procedural due process cannot be adopted: an individual's claim to a "nonalienating" procedure is not ranked ahead of all other social values.

The available techniques for limiting the procedural claims elicited by the dignitary theory, however, either appear arbitrary or render the theory wholly inoperative. One technique is to curtail the class of substantive claims in which individuals can be said to have a right to what they consider an acceptable procedure. The "life, liberty, or property" language of the due process clause suggests such a limitation, but experience with this classification of interests has been disappointing. ${ }^{69}$ Any standard premised simply on preexisting legal rights renders a claimant's quest for due process, as such, either unnecessary or hopeless. ${ }^{70}$ Another technique for confining the dignitary theory is to define "nonalienating" procedure as any procedure that is formulated democratically. The troublesome effect of this limitation is that no procedures that are legislatively

"See discussion in E. Redford, Democracy in the Administrative State 6-9, 19-22 (1969).

${ }^{87}$ The Supreme Court might decide in particular cases, of course, that even a statutory provision for "hearing" does not contemplate a requirement of oral presentation. See, e.g., United States v. Florida East Coast Ry., 410 U.S. 224 (1973). See also Friendly, Some Kind of Hearing, 123 U. PA. L. REv. 1267, 1270 (1975). I tend, nevertheless, to agree with Professor Davis that "hearing" implies an oral proceeding. $1 \mathrm{~K}$. Davis, Administrative LAW Treatise $\S$ 7.01, at 310-11 (Supp. 1970).

ax See generally Summers, Evaluating and Improving Legal Processes-A Plea for "Process Values," 60 Cornell L. Rev. 1 (1974).

"See generally Van Alstyne, The Demise of the Right-Privilege Distinction in Constitutional Law, 81 Harv. L. Rev. 1439 (1968); Reich, Individual Rights and Social Welfare: The Emerging Legal Issues, 74 YALE L.J. 1245 (1965).

70 See, e.g., Arnett v. Kennedy, 416 U.S. 134, 164-67 (1974) (Powell, J., concurring). 
authorized can be said to encroach on individual dignity."

Notwithstanding its difficulties, the dignitary theory of due process might have contributed significantly to the Eldridge analysis. The questions of procedural "acceptability" which the theory poses may initially seem vacuous or at best intuitive, but they suggest a broader sensitivity than the utilitarian factor analysis to the nature of governmental decisions. Whereas the utilitarian approach seems to require an estimate of the quantitative value of the claim, the dignitary approach suggests that the Court develop a qualitative appraisal of the type of administrative decision involved. While the disability decision in Eldridge may be narrowly characterized as a decision about the receipt of money payments, it may also be considered from various qualitative perspectives which seem pertinent in view of the general structure of the American income-support system.

That system suggests that a disability decision is a judgment of considerable social significance, and one that the claimant should rightly perceive as having a substantial moral content. The major cash income-support programs ${ }^{72}$ determine eligibility, not only on the basis of simple insufficiency of income, but also, or exclusively, on the basis of a series of excuses for partial or total nonparticipation in the work force: agedness, childhood, family responsibility, injury, disability. A grant under any of these programs is an official, if sometimes grudging, stamp of approval of the claimant's status as a partially disabled worker or nonworker. It proclaims, in effect, that those who obtain it have encountered one of the politically legitimate hazards to self-sufficiency in a market economy. The recipients, therefore, are entitled to society's support. Conversely, the denial of an income-maintenance claim implies that the claim is socially illegitimate, and the claimant, however impecunious, is not excused from normal work force status.

These moral and status dimensions of the disability decision

"Contractarian theories attempt to provide a comprehensive view of social choice that is premised on individual dignity and that avoids the twin shoals of subjectivity and majoritarian tyranny. Discussion of current contractarian debate, revolving particularly around the contributions of John Rawls, would transcend the scope of this article. It may be noted, however, that the only attempt to make the Rawlsian approach operational with respect to legal procedures yields only an indication of subjective preferences unencumbered by cost, and therefore fails to elaborate principles of social choice in terms of Rawls's more general contractarian scheme. See generally J. Thibaut \& L. Walker, Procedural Justice: A Psychological ANalysis (1975).

${ }^{72}$ The major cash income-support programs available in the United States are contained in the Social Security Act, the statute establishing the Veterans' Assistance programs, and the state and federal workmen's compensation acts. 
indicate that there is more at stake in disability claims than temporary loss of income. ${ }^{73}$ They also tend to put the disability decision in a framework that leads away from the superficial conclusion that disability decisions are a routine matter of evaluating medical evidence. Decisions with substantial "moral worth" connotations are generally expected to be highly individualized and attentive to subjective evidence. The adjudication of such issues on the basis of documents submitted largely by third parties and by adjudicators who have never confronted the claimant seems inappropriate. Instead, a court approaching an analysis of the disability claims process from the dignitary perspective might emphasize those aspects of disability decisions that focus on a particular claimant's vocational characteristics, his unique response to his medical condition, and the ultimate predictive judgment of whether the claimant should be able to work.

\section{Equality}

Justice in a formal philosophical sense is often defined as equality of treatment. In the realm of adjudicatory procedure, a widely recognized aspect of procedural fairness is equality of opportunity to be heard. Indeed, insofar as adjudicatory procedure is perceived to be adversarial and dispute resolving, ${ }^{74}$ the degree to which procedures facilitate equal opportunities for the adversaries to influence the decision may be the most important criterion by which fairness is evaluated. ${ }^{75}$

Equality of opportunity is not, however, an exhaustive measure of procedural due process. ${ }^{76}$ While equality would seem to require an unbiased decision maker and identical opportunities to present evidence and argument, it has little to say concerning the manner in which evidence and argument are presented. A hearing participant might claim, for example, that oral proceedings, including cross-examination, would illuminate murky aspects of the case or produce a truer disclosure of facts; but if this participant's adver-

${ }^{73}$ The Eldridge Court, in distinguishing Goldberg largely on the ground that terminated welfare recipients were more desperate financially than terminated disability recipients, thus ignored a very substantial similarity. See text at note 42 supra. The potential for feelings of demoralization, rejection, or simple righteous indignation seems essentially the same in both types of cases.

"See Scott, Two Models of the Civil Process, 27 Stan. L. Rev. 937 (1975).

${ }^{75}$ See generally J. Thibaut \& L. WALKER, supra note 71.

${ }^{76}$ For an exhaustive listing of the elements of formal adjudicatory process and a discussion of their applicability in particular contexts, see Friendly, Some Kind of Hearings, 123 U. PA. L. REv. 1267 (1975). 
sary or other participants are not accorded these procedural rights, he can hardly claim unequal treatment. Similarly, objection to the use of material obtained outside the record, but not from a party, is at most remotely connected with equality of access. A procedure that divested the directly affected parties of all control over the process of shaping issues and developing evidence, indeed that never informed the parties that it had begun, would be "unequal" only if institutionally biased. ${ }^{77}$ Yet such a procedure would widely be perceived as "unfair."

Notions of equality can nevertheless significantly inform the evaluation of any administrative process. One question we might ask is whether an investigative procedure is designed in a fashion that systematically excludes or undervalues evidence that would tend to support the position of a particular class of parties. If so, those parties might have a plausible claim that the procedure treated them unequally. Similarly, in a large-scale inquisitorial process involving many adjudicators, the question that should be posed is whether like cases receive like attention and like evidentiary development so that the influence of such arbitrary factors as location are minimized. In order to take such equality issues into account, we need only to broaden our due process horizons to include elements of procedural fairness beyond those traditionally associated with adversary proceedings. These two inquiries might have been pursued fruitfully in Eldridge. First, is the state agency system of decision making, which is based on documents, particularly disadvantageous for certain classes of claimants? There is some tentative evidence that it is. ${ }^{78}$ Cases such as Eldridge involving muscular or skeletal disorders, neurological problems, and multiple impairments, including psychological overlays, are widely believed to be both particularly difficult, due to the subjectivity of the evidence, and particularly prone to be reversed after oral hearing.

Second, does the inquisitorial process at the state agency level tend to treat like cases alike? If the GAO's study ${ }^{79}$ is indicative, the answer is decidedly no. According to that study, many, perhaps

$"$ See, e.g., F. KAfKa, ThE Trial (3d ed. 1956). Kafka gained many of his impressions of administrative processes as a bureaucrat in an agency dispensing disability benefits. $M$. Brod, Franz KaFKa 79-84 (1970).

${ }^{7 \pi}$ See W. Popkin, Counsel in the Welfare State: A Statistical and Legal Analysis of the Role of Representation in Administrative Decision-Making Based on a Study of Five Disability Programs 34, 52-53, 59-61 (1975). (This is a draft report to the Administrative Conference Committee on Grant and Benefit Programs. It has not been approved by the Committee or the Conference and represents only the view of its author.)

"See text and notes at 56-57 supra. 
half, of the decisions are made on the basis of records that other adjudicators consider so inadequate that a decision could not be rendered. The relevance of such state agency variance to Eldridge's claim is twofold: first, it suggests that state agency determinations are unreliable and that further development at the hearing stage might substantially enhance their reliability; alternatively, it may suggest that the hierarchical or bureaucratic model of decision making, with overhead control for consistency, does not accurately describe the Social Security disability system. And if consistency is not feasible under this system, perhaps the more compelling standard for evaluating the system is the dignitary value of individualized judgment, which, as noted earlier ${ }^{80}$ implies claimant participation.

\section{Tradition or Evolution}

Judicial reasoning, including reasoning about procedural due process, is frequently and self-consciously based on custom or precedent. In part, reliance on tradition or "authority" is a court's institutional defense against illegitimacy in a political democracy. But tradition serves other values, not the least of which are predictability and economy of effort. More importantly, the inherently conservative technique of analogy to custom and precedent seems essential to the evolutionary development and the preservation of the legal system. ${ }^{81}$ Traditional procedures are legitimate not only because they represent a set of continuous expectations, but because the body politic has survived their use.

The use of tradition as a guide to fundamental fairness is vulnerable, of course, to objection. Since social and economic forces are dynamic, the processes and structures that proved functional in one period will not necessarily serve effectively in the next. Indeed, evolutionary development may as often end in the extinction of a species as in adaptation and survival. For this reason alone tradition can serve only as a partial guide to judgment.

Furthermore, it may be argued that reasoning by analogy from traditional procedures does not actually provide a perspective on

\footnotetext{
so See text at notes 66-67 supra.

si See generally F. HayeK, Law, Legislation and Liberty: A New Statement of the Liberal Principles of Justice and Polttical Economy (1973). This general approach can be though of as "Burkean," or as representative of the traditional viewpoint of anticode continental thinkers such as Von Savigny. See, e.g., F. O'Gorman, Edmund Burke 45-66 (1973); F. Von Savigny, Of the Vocation of Our Age for Legislation and Jurisprudence (A. Hayward trans. 1975).
} 
the values served by due process. Rather, it is a decisional technique that requires a specification of the purposes of procedural rules merely in order that the decision maker may choose from among a range of authorities or customs the particular authority or custom most analogous to the procedures being evaluated.

This objection to tradition as a theory of justification is weighty, but not devastating. What is asserted by an organic or evolutionary theory is that the purposes of legal rules cannot be fully known. Put more cogently, while procedural rules, like other legal rules, should presumably contribute to the maintenance of an effective social order, we cannot expect to know precisely how they do so and what the long-term effects of changes or revisions might be. Our constitutional stance should therefore be preservative and incremental, building carefully, by analogy, upon traditional modes of operation. So viewed, the justification "we have always done it that way" is not so much a retreat from reasoned and purposive decision making as a profound acknowledgment of the limits of instrumental rationality.

Viewed from a traditionalist's perspective, the Supreme Court's opinion in Eldridge may be said to rely on the traditional proposition that property interests may be divested temporarily without hearing, provided a subsequent opportunity for contest is afforded. Goldberg $v$. Kelly is deemed an exceptional case, from which Eldridge is distinguished.

Like the Court's utiliarian analysis, this general traditionalist method seems incomplete. If the premise of that method is that traditional modes of operation are to provide guidelines, then the Court should have immediately characterized the legal issue in order to select the appropriate guidelines. But given the Court's quite sensible position that administrative functions are to be evaluated individually, how was that characterization to proceed? Presumably, disability payments fall within the general domain of social welfare claims-a domain that is also treated in the Goldberg decision. Assuming, however, that the Court properly distinguished Goldberg, analogical analysis is aborted because no other Supreme Court decision pertaining to social welfare claims seems apt. Nor could it discover guiding authority in prior administrative practice, which is based on the now discredited notion that social welfare benefits are subject to discretionary divestiture. What the Eldridge Court needed, then, was a more general way of thinking about the termination of property interests that might apply both to traditional and to novel forms of property.

The beginnings of such an approach might be found in Justice 
Black's dissent in Goldberg, ${ }^{82}$ where he analogized the position of a welfare recipient to the traditional position of a creditor when his debtor refuses further performance. Normally, in that situation, the creditor is left with the inconvenience of forgoing receipt of performance while he seeks legal enforcement of an obligation that may or may not remain due. The majority opinion's implicit response to the analogy is that a welfare recipient is in a special position: he literally cannot wait because he depends upon the state's performance for survival. Given this special circumstance, the Court concludes, the traditional bearer of the risk of erroneous (or otherwise illicit) nonperformance has a constitutional right to shift that risk to the state, pending hearing. Given this reading of Goldberg, the Eldridge opinion may be interpreted as concluding simply that the special Goldberg circumstances did not obtain. Therefore, the traditional allocation of the risk was acceptable.

Analyzing Goldberg and Eldridge by analogy to traditional contract-default remedies is valuable because it discourages the superficial classification of welfare recipients as immediately desperate and of disability recipients as having alternative resources. A court in equity faced with an analogous issue-a request for a temporary restraining order or preliminary injunction to insure performance by an obligor-would look to the particular circumstances of the case to determine whether extraordinary remedies were justified. In so doing, the court would take into account the peculiar hardship to the plaintiff of nonperformance pending a trial, the likelihood that he might prevail on the merits, and the burden on the defendant of requiring maintenance of the status quo. ${ }^{83}$ The Social Security Administration, as a matter of due process of law, might sensibly be required to do the same-or at least to explain its inability to do so.

A court pursuing an analysis based on traditional contractdefault remedies should also focus on the limitations of that analogy. Contract remedies presume a competitive market in which alternative obligors are available. This presumption of the availability of alternatives undergirds traditional judicial reluctance to require specific performance pending trial, or indeed after trial. The party relying on state support is in a quite different position. His market alternatives have previously been determined to be fore-

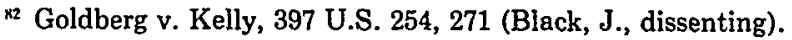

${ }^{43}$ See, e.g., Kaiser Trading Co. v. Associated Metals \& Minerals Corp., 321 F. Supp. 923 (N.D. Cal. 1970), appeal dismissed, 443 F.2d 1364 (9th Cir. 1971). See generally D. DoBBS, HaNDBoOK ON THE LaW of Remedies 108-11 (1973). 
closed, and his attachment to a particular income-maintenance scheme suggests that others are at best not comparable, and at worst unavailable. While this difference between contract and income-maintenance claims may not be a sufficient reason for reversing the usual allocation of the risk of error pending a full hearing in all cases, it comes close to presenting an a fortiori case for requiring that the individual income-maintenance claimant, like the contract creditor, be allowed to establish (perhaps by affidavit) that his is such a case.

\section{ConcLusion}

The preceding discussion has emphasized the way that explicit attention to a range of values underlying due process of law might have led the Eldridge Court down analytic paths different from those that appear in Justice Powell's opinion. The discussion has largely ignored, however, arguments that would justify the result that the Court reached in terms of the alternative value theories here advanced. Those arguments are now set forth.

First, focus on the dignitary aspects of the disability decision can hardly compel the conclusion that an oral hearing is a constitutional necessity prior to the termination of benefits when a full hearing is available later. Knowledge that an oral hearing will be available at some point should certainly lessen disaffection and alienation. Indeed, Eldridge seemed secure in the knowledge that a just procedure was available. ${ }^{84}$ His desire to avoid taking a corrective appeal should not blind us to the support of dignitary values that the de novo appeal provides.

Second, arguments premised on equality do not necessarily carry the day for the proponent of prior hearings. The Social Security Administration's attempt to routinize and make consistent hundreds of thousands of decisions in a nationwide incomemaintenance program can be criticized both for its failures in its own terms and for its tendency to ignore the way that disability decisions impinge upon perceptions of individual moral worth. On balance, however, the program that Congress enacted contains criteria that suggest a desire for both consistency and individualization. No adjudicatory process can avoid tradeoffs between the pursuit of one or the other of these goals. Thus a procedural structure incorporating (1) decisions by a single state agency based on a documentary record and subject to hierarchical quality review, fol-

"s See text at note 25 supra. 
lowed by (2) appeal to de novo oral proceedings before independent administrative law judges, is hardly an irrational approach to the necessary compromise between consistency and individualization.

Explicit and systematic attention to the values served by a demand for due process nevertheless remains highly informative in Eldridge and in general. The use of analogy to traditional procedures might have helped rationalize and systematize a concern for the "desperation" of claimants that seems as impoverished in Eldridge as it seems profligate in Goldberg; and the absence in Eldridge of traditionalist, dignitary, or egalitarian considerations regarding the disability adjudication process permitted the Court to overlook questions of both fact and value-questions that, on reflection, seem important. The structure provided by the Court's three factors is an inadequate guide for analysis because its neutrality leaves it empty of suggestive value perspectives.

Furthermore, an attempt by the Court to articulate a set of values that informs due process decision making might provide it with an acceptable judicial posture from which to review adminstrative procedures. The Goldberg decision's approach to prescribing due process-specification of the attributes of adjudicatory hearings by analogy to judicial trial-makes the Court resemble an administrative engineer with an outdated professional education. It is at once intrusive and ineffectual.$^{85}$ Retreating from this stance, the Eldridge Court relies on the administrator's good faith-an equally troublesome posture in a political system that depends heavily on judicial review for the protection of countermajoritarian values.

The path to a more appropriate and successful judicial role may lie in giving greater attention to the elaboration of the due process implications of the values that have been discussed. If the Court provided a structure of values within which procedures would be reviewed, it could then demand that administrators justify their processes in terms of the degree to which they support the elaborated value structure. The Court would have to be satisfied that the administrator had carefully considered the effects of his chosen procedures on the relevant constitutional values and had made reasonable judgments concerning those effects.

A decision that an administrator had not met that standard would not result in the prescription of a particular adjudicatory technique as a constitutional, and thereafter virtually immutable,

*s See generally Mashaw, The Management Side of Due Process: Some Theoretical and Litigation Notes on the Assurance of Accuracy, Fairness, and Timeliness in the Adjudication of Social Welfare Claims, 59 CoRnell L. REv. 772 (1974). 
necessity; but rather in a remand to the administrator. In meeting the Court's objections, the administrator (or legislature) might properly choose between specific amendment and a complete overhaul of the administrative process. Perhaps more importantly, under a due process approach that emphasized value rather than technique, neither the administrator in constructing and justifying his processes, nor the Court in reviewing them, would be limited to the increasingly sterile discussion of whether this or that particular aspect of trial-type procedure is absolutely essential to due process of law. 